\title{
ESTIMATES OF THE CONTRIBUTION OF FOG WATER TO WET ATMOSPHERIC DEPOSITION IN CZECH MOUNTAIN FORESTS BASED ON ITS STABLE HYDROGEN AND OXYGEN ISOTOPE COMPOSITION: PRELIMINARY RESULTS
}

\author{
IVA HŮNOVÁ ${ }^{1,2, *}$, DARINA HANUSKOVÁ1 ${ }^{1}$, KATEŘINA JANDOVÁ1, \\ MIROSLAV TESAŘ ${ }^{3}$, JIŘí KVĚTOŇ ${ }^{4,5}$, and JAROSLAV KUKLA ${ }^{1}$
}

\footnotetext{
${ }^{1}$ Charles University, Faculty of Science, Institute for Environmental Studies, Benátská 2, 12800 Prague 2, Czech Republic

${ }^{2}$ Czech Hydrometeorological Institute, Na Šabatce 17, 14306 Prague 4 - Komořany, Czech Republic

${ }^{3}$ Institute of Hydrodynamics of the Czech Academy of Sciences, Pod Patankou 30/5, 16612 Prague 6, Czech Republic

${ }^{4}$ Department of Experimental Plant Biology, University of South Bohemia, Branišovská 1716, 370 05, České Budějovice, Czech Republic

${ }^{5}$ Institute of Experimental Botany of the Czech Academy of Sciences, Rozvojová 263, 16502 Prague, Czech Republic

*Corresponding author: iva.hunova@chmi.cz
}

\begin{abstract}
Stable isotopes are increasingly being used in many scientific fields, including environmental sciences. In this study we measured the variation in the stable hydrogen and oxygen isotope composition of fog water, rain water (in the form of bulk falling precipitation) and throughfall water in the Šumava (the Bohemian Forest), Krkonoše (the Giant Mts.) and Jizerské hory (the Jizera Mts.) Mts. in October-November 2017. In total, 46 cumulative two-week samples were collected and analysed. Our results indicate that the overall stable hydrogen and oxygen isotope composition of fog and rain samples differed significantly, fog being isotopically enriched in the heavier isotopes ${ }^{2} \mathrm{H}$ and ${ }^{18} \mathrm{O}$ relative to rain. In contrast to our assumption, throughfall water was generally depleted in the heavier isotopes ${ }^{2} \mathrm{H}$ and ${ }^{18} \mathrm{O}$ relative to rainwater. Hence, the simple mixing model for most samples yielded an unrealistic percentage outside the reasonable range of $0-100 \%$. For few samples, however, the estimated contribution of fog to throughfall ranged between 3 and $8 \%$ based on $\delta^{2} \mathrm{H}$ and 4 and $7 \%$ based on $\delta{ }^{18} \mathrm{O}$, which is lower than that estimated for the same mountain regions by other authors using different methods and significantly lower than that reported for mountain ranges in neighbouring countries. Although using stable isotopes is a promising tool for determining the contribution of fog to the hydrological budget when assessing atmospheric deposition, the critical limitations are in the collection, manipulation and storing of the samples.
\end{abstract}

Keywords: atmospheric deposition; fog; rain; stable hydrogen and oxygen isotopes; throughfall

\section{Introduction}

Atmospheric deposition is important in contributing to the self-cleaning of the atmosphere while being a significant source of pollution for the Earth surface (Amodio et al. 2014). It is comprised of wet, dry and occult deposition (Seinfeld and Pandis 2006). While the wet deposition in the form of falling precipitation (episodically in occurrence, related to rain and snow) is relatively easy to measure, dry deposition (occurring continuously via gases or aerosols) is much more difficult to quantify and occult deposition (i.e. fog and rime) is mostly not accounted for at all. It is widely accepted, however, that an accurate quantification of the real atmospheric deposition flux is an essential prerequisite for linking it to its possible environmental effects. While the volume of rain or snow is fairly easy to determine, the water input of occult precipitation (deposition of fog and cloud droplets) and its contribution to meteoric water budget is mostly uncertain. It is well known that occult precipitation may play an important role in both water and ion inputs, particularly in mountain and coastal regions (e.g. Rogora et al. 2006; Schmid et al. 2011; Blaš et al. 2012). Nevertheless, the occult deposition is very difficult to measure and rarely recorded, and not included in regular monitoring networks (Schemenauer and Cereceda 1994).
Stable hydrogen and oxygen isotope composition of meteoric water is an elegant tool for studying different environmental processes (Sharp 2007; Šantrůček et al. 2018). In particular, it is widely used in hydrology for studying the hydrological cycle and water budget (e.g. Soulsby et al. 2000; Votrubová et al. 2017; Zhan et al. 2017). In addition, it has proved useful in climatology, as there are close relationships between climatically relevant meteorological variables, such as surface air temperature or moisture and stable hydrogen and oxygen isotope composition of precipitation (Rozanski et al. 1992; Ichiyanagi 2007). The isotopic approach is used in studies on fog, mostly for identifying its origin (Kaseke et al. 2018). In addition, it was successfully used to estimate the hydrological input of occult precipitation in atmospheric deposition (Dawson 1998; Scholl et al. 2007), as the stable isotope composition of local fog water differs significantly from local rainwater (Fischer and Still 2007).

Fog plays a significant role generally in the maintenance of ecosystems (Weathers et al. 2020) and specifically in the CR, based both on direct measurements (Tesar et al. 2000; Bridges et al. 2002; Bridgman et al. 2002; Fišák et al. 2002; Křeček et al. 2017; Palán and Křeček 2018) and data-driven models (Hůnová et al. 2011, 2016), in which it substantially enhances total atmospheric deposition of environmentally relevant substances, particularly in mountain forested areas (Igawa et al. 2002; Lange 
et al. 2003). Stable hydrogen and oxygen isotope composition of rain has been used in the CR to study the role of rain in the hydrological balance in small water catchments (Šanda et al. 2011, 2019), whereas that of fog has not been measured.

The aim of this study, carried out at the Institute of Environmental Sciences (Hanusková 2018) was to measure the stable hydrogen and oxygen isotope composition of fog, rain and throughfall. We hypothesised that their isotopic compositions would differ significantly and that by using the simple isotopic mixing model, it would be possible to estimate the contribution of fog to wet atmospheric deposition in mountain forests in the Czech Republic.

\section{Methods}

\section{Sampling of fog, rain and throughfall}

In order to collect samples of cloudwater, sampling devices were constructed. Two methods of sampling were used. In the first: the active cloud and fog water collector (see photograph in Fig. 1a), in which fog is collected by using a fan to draw air across 10 rows of vertical Teflon strands of $0.5-0.87 \mathrm{~mm}$ diameter, which are fixed to a support inside a Plexiglas box at one end of which is the fan. Air enters the box through an opening in the bottom of the box. These so-called active CWP collectors are described in literature by Daube et al. (1987) and were used extensively in research on fog in the U.S.A. (Weathers et al. 1988) and in Europe in the Bohemian Forest and Ore Mts in the Czech Republic (Tesař et al. 1995) and Taunus Mts. in Germany (Eliáš et al. 1995). In the second, so-called passive cloud and fog water collector, fog is collected passively (see photographs in Fig. 1b and 1c), i.e. fog droplets were captured on Teflon strings $0.5-0.87 \mathrm{~mm}$ in diameter mounted alongside one another to form a curtain in the form of a truncated cone. This "Grunow" type of fog gauge (Grunow 1952) is shielded from rain by a $0.5 \mathrm{~m}^{2}$ roof. This passive cloud and fog water collector was first advertised at the 2nd International Conference on Fog and Fog Collection in Canada in 2001 (Tesař et al. 2001).

Samples collected were stored in 500 or $1000 \mathrm{ml}$ polyethylene bottles at $4{ }^{\circ} \mathrm{C}$ in the dark. Prior to use, storage bottles were washed with $6 \mathrm{~N} \mathrm{HCl}$, followed by several rinses with distilled water.

For this study, we sampled fog, rain and throughfall. In meteorology, fog is defined as an obscurity in the surface layer of atmosphere caused by a suspension of water droplets reducing horizontal visibility at least in one direction to less than $1000 \mathrm{~m}$ (ČMES 2020). Thus, apart from genuine fog, a cloud touching the Earth surface is also perceived as fog. The most accurate way to distinguish fog from rain is by droplet size, with fog consisting of tiny water droplets, typically $10-20 \mu \mathrm{m}$ in diameter and rain of drops greater than $0.5 \mathrm{~mm}$ in diameter
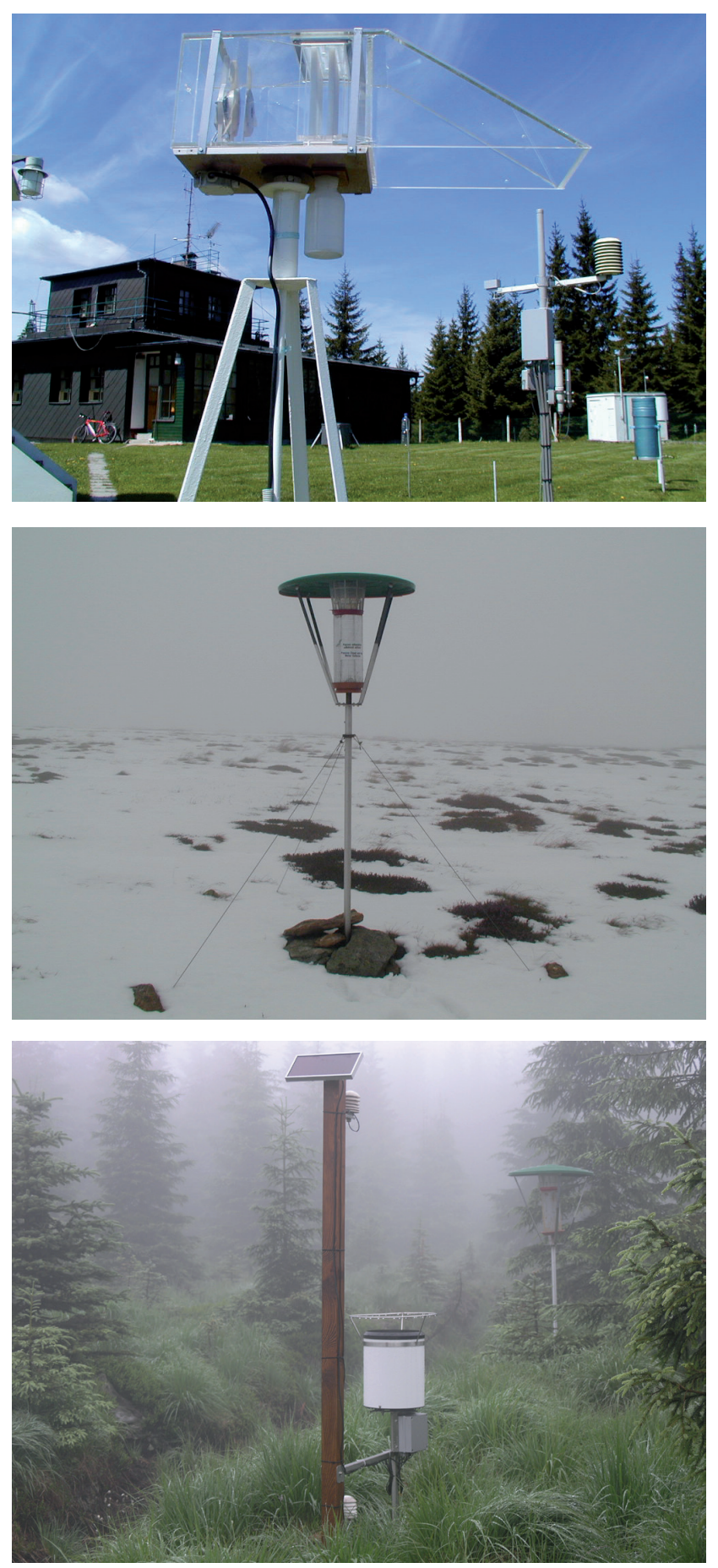

Fig. 1 Fog samplers: (a) active fog sampler, Sum_CH, (b) passive fog sampler, KrK_SH and (c) passive fog sampler in the background with rain sampler in the foreground, Jiz_CN, photographer: M. Tesař.

(Scholl et al. 2011), i.e. large enough to fall into a conventional rain gauge. Throughfall is precipitation collected underneath vegetation, which consists of both precipitations intercepted by the canopy that then drips on to the ground and precipitation falling directly through gaps in the canopy. Throughfall is often used in environmental studies to quantify the input part of the geochemical balance (Bellot et al. 1999). Photographs of the fog and rain samplers used at some of our sites are presented in Fig. 1. 


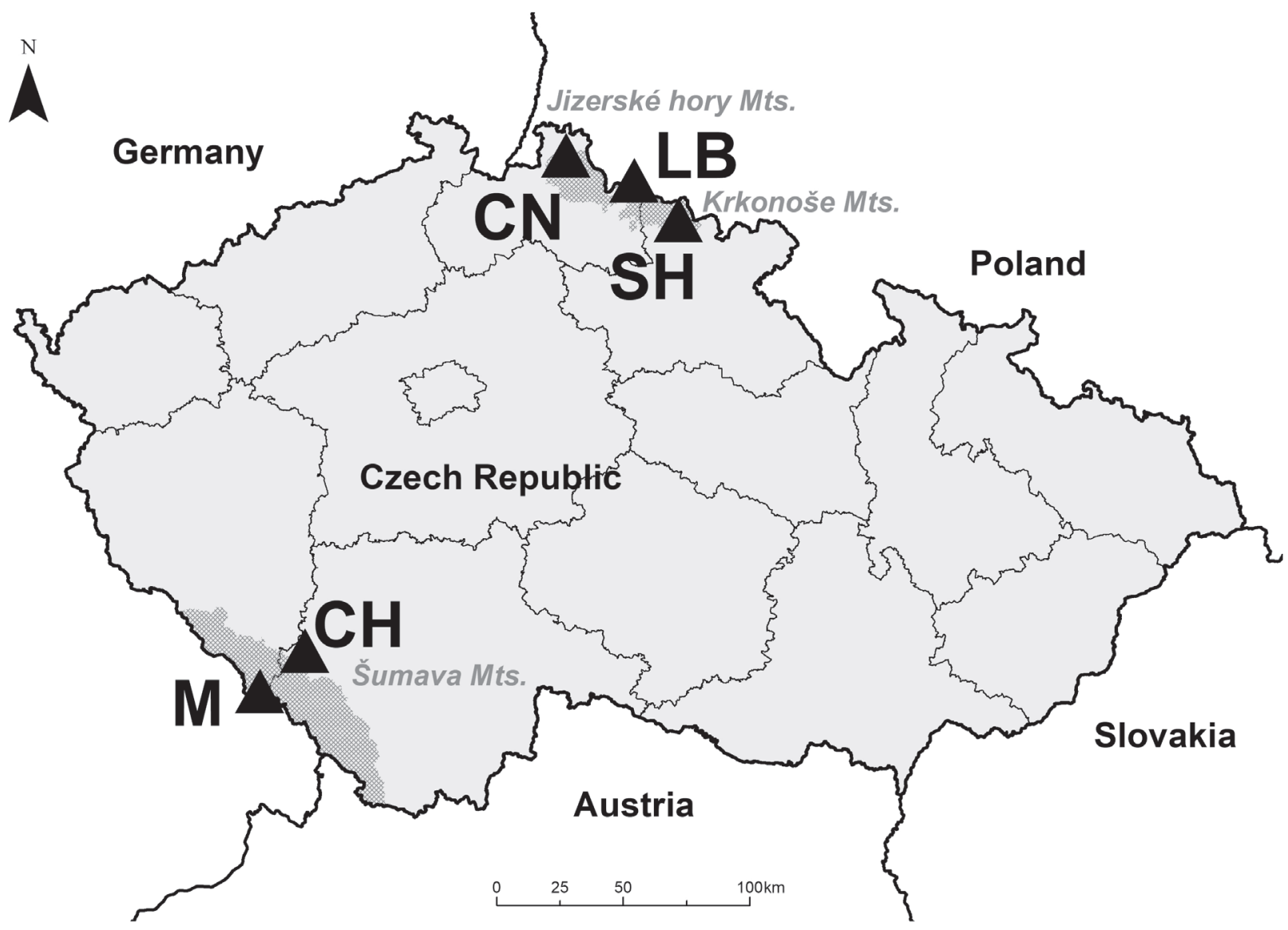

Fig. 2 Map showing the locations of the sites sampled.

The throughfall samples were assumed to be a mixture of fog and rainwater.

In this study, a bulk precipitation sampler for rainwater was located close to the fog sampler, whereas one identical precipitation sampler was placed under a tree for collecting throughfall (spruce trees in the Šumava Mts., dwarf pines in the Krkonoše Mts). The throughfall sampler was placed under branches some distance from the tree trunk in order to ensure the representativeness of the samples as much as possible.

\section{Sites sampled}

For this study, we used five established sites situated in three Czech mountain regions: Krkonoše (the Giant Mts.), Jizerské hory (the Jizera Mts.) and Šumava Mts. (the Bohemian Forest) (Fig. 2, Table 1). The Krkonoše and Jizerské hory Mts., located in the northern part of the CR bordering on Poland, belonged in the past to the so called Black Triangle region, infamous for heavy ambient air pollution particularly in the 1970s and 1980s (Hůnová 2020). In contrast, the Šumava Mts., are in the southern part of the CR bordering on Austria and is the cleanest part of the CR (CHMI 2019).

In the Krkonoše Mts., Labská bouda (1355 m a.s.l.) and Studniční hora (1550 m a.s.l.) are the sites, where fog (passive samplers), rain and throughfall were sampled. The vegetation at these sites consists of artic-alpine tundra with dwarf pine, Pinus mugo (Šír and Tesař
2013). In the Šumava Mts., Churáňov (1123 m a.s.l.) and Malá Mokrůvka (1300 m a.s.l.) are the sites where fog (Churáňov active sampler, Malá Mokrůvka passive sampler), rain and throughfall (in spruce, Picea abies, stands) were sampled. The hilltop station at Churáñov is part of the network of professional meteorological stations run by the Czech Hydrometeorological Institute. In addition, it is the site with the longest record of horizontal (occult) deposition for the hydrological and geochemical balance of a small mountain water catchment (Tesař et al. 2000). Only one site in the Jizerské hory Mts., Prameny Černé Nisy, was sampled for fog and rainwater (for technical reasons the throughfall was not sampled). This site is situated within the Uhliřrska water catchment and is part of the international monitoring of stable isotopes within the GNIP (Global Network of Isotopes in Precipitation) and GNIR (Global Network of Isotopes in Rivers) networks (Šanda et al. 2011).

\section{Period sampled}

Samples of fog, rain and throughfall were collected from October to November in 2017. The selection of October and November was because the highest occurrence of fog in the CR is in the late autumn/winter periods (Tolasz et al. 2007; Hůnová et al. 2020). For practical reasons, based on previous experience, it was most convenient to sample fog before December, as in January and February sampling (and generally access to 
Table 1 Characteristics of the sites sampled.

\begin{tabular}{|c|c|c|c|c|c|c|}
\hline Mountain region & Site sampled & Code & Coordinates & Altitude [m a.s.l.] & Fog sampler & Samples \\
\hline \multirow{2}{*}{ Krkonoše } & Studniční hora & KrK_SH & $\begin{array}{c}50.7265272 \mathrm{~N} \\
15.7051425 \mathrm{E}\end{array}$ & 1550 & passive & $F, R, T$ \\
\hline & Labská bouda & KrK_LB & $\begin{array}{c}50.7703075 \mathrm{~N} \\
15.5412983 \mathrm{E}\end{array}$ & 1355 & passive & $F, R, T$ \\
\hline \multirow[t]{2}{*}{ Šumava } & Malá Mokrůvka & Sum_M & $\begin{array}{c}48.9702228 N, \\
13.5123172 \mathrm{E}\end{array}$ & 1300 & passive & $F, R, T$ \\
\hline & Churáňov & Sum_CH & $\begin{array}{c}49.0682161 \mathrm{~N} \\
13.6152428 \mathrm{E}\end{array}$ & 1123 & active, passive & $F, R, T$ \\
\hline Jizerské hory & Prameny Černé Nisy & $\mathrm{Jiz} \_\mathrm{CN}$ & $\begin{array}{c}50.8400925 \mathrm{~N}, \\
15.1518536 \mathrm{E}\end{array}$ & 820 & passive & $F, R$ \\
\hline
\end{tabular}

Note: $F$ - fog, $R$ - rain, $T$ - throughfall

the sampling site) can be difficult due snow cover. Twoweek cumulative samples were collected in both months. For the Šumava and Jizerské hory Mts., the samples were available for both October and November, whereas for the Krkonoše Mts. only for October. In total 46 samples were collected.

\section{Stable hydrogen and oxygen isotope analyses}

Water samples were pipetted into $1.5-\mathrm{ml}$ glass vials, crimped and stored upside down (to prevent water vapour exchange with ambient atmosphere) in a refrigerator prior to analyses. Stable isotope composition of water was determined using an isotope ratio mass spectrometer (IRMS) (DeltaPlus XL, ThermoFinnigan, Bremen, Germany) coupled to a high-temperature conversion elemental analyser (TC/EA ThermoFinnigan, Bremen, Germany) at the University of South Bohemia in České Budejjovice. A volume of $1 \mu \mathrm{l}$ was injected into the reactor heated to $1400{ }^{\circ} \mathrm{C}$ using a COMBI PAL autosampler (CTC Analytics AG, Zwingen, Switzerland). Then, the gases produced were separated using a molecular sieve heated to $85^{\circ} \mathrm{C}$ before finally entering the IRMS. There were three replicate injections of each sample, the first of which was not included in the calculations due to a memory effect. The hydrogen and oxygen isotope ratios are expressed as follows: $\delta \mathrm{X}[\%]=\left(\mathrm{R}_{\text {sample }} / \mathrm{R}_{\text {standard }}\right.$ $-1) \times 1000$, where $\mathrm{X}$ is ${ }^{2} \mathrm{H}$ or ${ }^{18} \mathrm{O}$ and $\mathrm{R}$ is the relative abundance of hydrogen or oxygen isotopes $\left(\mathrm{R}={ }^{2} \mathrm{H} /{ }^{1} \mathrm{H}\right.$ or ${ }^{18} \mathrm{O} /{ }^{16} \mathrm{O}$ ). The isotope ratios were normalised based on the internatinal standards Vienna Standard Mean Ocean Water 2 (V-SMOW 2) and Greenland Ice Sheet Precipitation (GISP) and reported on the V-SMOW scale according to Nelson (2000). The standard deviations of repeatedly measured international standards indicating the precision of the measurements are shown in Table 2.

Table 2 Precision of our measurements.

\begin{tabular}{|l|c|c|}
\hline & \multicolumn{2}{|c|}{ Standard deviation, $\mathrm{n}=10$} \\
\hline & $\boldsymbol{\delta}^{\mathbf{2}} \mathbf{H}[\%$ o] & $\boldsymbol{\delta}^{18} \mathbf{O}[\%$ ] $]$ \\
\hline V-SMOW 2 & 1.5 & 0.24 \\
\hline GISP & 1.8 & 0.37 \\
\hline
\end{tabular}

\section{Calculation of the hydrological contribution to atmospheric deposition}

At localities, where fog and rain have distinct isotopic compositions, a simple linear mixing model may be used to determine the contributions of these two sources to throughfall (Scholl et al. 2011). The fraction of throughfall that comes from fog $f_{\mathrm{F}}$ is estimated using a simple mixing model:

$f_{\mathrm{F}}=\left(\delta_{\mathrm{T}}-\delta_{\mathrm{R}}\right) /\left(\delta_{\mathrm{F}}-\delta_{\mathrm{R}}\right)$

Where:

$\delta$ denotes the isotopic values $\left(\delta^{2} \mathrm{H}\right.$ or $\left.\delta^{18} \mathrm{O}\right)$,

$F$ denotes the sampled fog,

$T$ denotes the sampled throughfall,

$R$ denotes the sampled rain.

\section{Results}

Our results for individual samples from particular sites are summarised in Table 3 and visualized in Fig. 3. The $\delta^{18} \mathrm{O}$ and $\delta^{2} \mathrm{H}$ values for individual samples regardless of their form range between $-12.6 \%$ and $-6.1 \%$, and $-84.6 \%$ and $-39.0 \%$, respectively. In terms of the form of the precipitation: the $\delta^{18} \mathrm{O}$ and $\delta^{2} \mathrm{H}$ values for (1) fog range between $-11.1 \%$ and $-6.1 \%$, and $-75.4 \% 0$ and $-39.0 \%$ respectively; for (2) rain between $-12.6 \%$ o and $-8.6 \%$, and $-83.6 \%$ and $-56.8 \%$, respectively; and for (3) throughfall between $-12.4 \%$ and $-8.0 \%$, and $-84.6 \%$ and $-55.4 \%$, respectively. The measured $\delta^{2} \mathrm{H}$ and $\delta^{18} \mathrm{O}$ values of the rain sampled were placed along the local meteoric water line (LMWL) expressed by the equation $\delta^{2} \mathrm{H}=7.028 \times \delta^{18} \mathrm{O}+4.78 \%$, which departs slightly from the global meteoric water line (GMWL), indicating the influence of evaporation and the fact that local precipitation originates from locally evaporated water.

Tables 4 and 5 presents average isotopic values for particular sites and regions, respectively. We have found that the fog samples were isotopically enriched in the heavier isotopes relative to rain in most cases with two 
Table $3 \delta^{2} \mathrm{H}$ and $\delta^{18} \mathrm{O}$ values for fog, rain and throughfall sampled in the Krkonoše, Šumava and Jizerské hory Mts.

\begin{tabular}{|c|c|c|c|c|c|c|c|}
\hline \multirow[t]{2}{*}{ Site } & \multirow[t]{2}{*}{ Date sampled } & \multicolumn{3}{|c|}{$\delta^{2} \mathbf{H}[\% \circ]$} & \multicolumn{3}{|c|}{$\delta^{18} 0$ [\%o] } \\
\hline & & $\mathbf{F}$ & $\mathbf{R}$ & $\mathbf{T}$ & $\mathbf{F}$ & $\mathbf{R}$ & $\mathbf{T}$ \\
\hline KrK_SH & 2.10 & -54.8 & -77.3 & -84.6 & -8.7 & -11.3 & -12.3 \\
\hline KrK_SH & 16.10 & -49.1 & -58.1 & -62.2 & -7.7 & -8.7 & -9.4 \\
\hline KrK_LB & 2.10. & -64.9 & -83.6 & -84.5 & -9.9 & -12.6 & -12.5 \\
\hline KrK_LB & 16.10. & -55.3 & -60.7 & -61.9 & -8.7 & -9.3 & -9.3 \\
\hline KrK_LB & 27.10. & -41.4 & -64.4 & 66.7 & -7.3 & -9.9 & -10.0 \\
\hline Sum_CH & 2.10 & -57.1 & -59.9 & 65.1 & -8.7 & -9.5 & -9.7 \\
\hline Sum_CH & 24.10. & -60.1 & -57.0 & -55.7 & -9.7 & -8.6 & -8.0 \\
\hline Sum_CH & 7.11. & -54.9 & -65.5 & -65.2 & -9.1 & -10.0 & -9.9 \\
\hline Sum_CH & 9.11. & -61.0 & -83.3 & -82.6 & -9.9 & -12.6 & -12.4 \\
\hline Sum_M & 25.10 & -39.0 & -56.8 & -55.4 & -6.1 & -8.6 & -9.0 \\
\hline Sum_M & 14.11 & -75.4 & -65.5 & -63.7 & -11.1 & -10.3 & -10.0 \\
\hline Jiz_CN & 6.10. & -55.3 & -60.0 & n.s. & -9.1 & -9.3 & n.s. \\
\hline Jiz_CN & 6.11. & -47.1 & -59.1 & n.s. & -7.9 & -9.5 & n.s. \\
\hline
\end{tabular}

Note: F - fog, R - rain, T - throughfall, Krk SH - Krkonoše-Studniční hora, KrK LB - Krkonoše-Labská bouda, Sum CH - Šumava-Churáňov, Sum M Šumava - Mokrůvka, Jiz - Jizerské hory Mts., Values when fog is not isotopically enriched in the heavier isotopes relative to rain are indicated in italics, n.s. - not sampled

Table $4 \delta^{2} \mathrm{H}$ and $\delta^{18} \mathrm{O}$ values of fog, rain and throughfall samples averaged for each of the sites sampled.

\begin{tabular}{|l|c|c|c|c|c|c|c|}
\hline \multirow{2}{*}{ Site } & \multirow{2}{*}{ Dates sampled } & \multicolumn{3}{|c|}{$\delta^{2} \mathbf{H}[\%$ ] } & \multicolumn{2}{c|}{$\delta^{180}[\%$ ] } \\
\cline { 3 - 8 } & & $\mathbf{F}$ & $\mathbf{R}$ & $\mathbf{T}$ & $\mathbf{F}$ & $\mathbf{R}$ & -10.8 \\
\hline KrK_SH & $2.10 / 16.10$. & -54.8 & -67.7 & -73.4 & -8.2 & -10.0 & -10.6 \\
\hline KrK_LB & $2 / 16 / 27.10$. & -53.9 & -69.6 & -71.1 & -8.6 & -10.6 & -10.0 \\
\hline Sum_CH & $2,24.10 / 7,9.11$. & -58.3 & -66.4 & -67.1 & -9.4 & -10.2 & -9.5 \\
\hline Sum_M & $25.10 / 14.11$. & -62.8 & -53.8 & -59.7 & -8.2 & -9.9 & n. s. \\
\hline Jiz_CN & $6.10 / 6.11$. & -51.1 & -59.5 & n. s. & -8.5 & -9.4 & T. \\
\hline
\end{tabular}

Note: $\mathrm{F}$ - fog, $\mathrm{R}$ - rain, T - throughfall, Krk_SH - Krkonoše-Studniční hora, KrK_LB - Krkonoše-Labská bouda, Sum_CH - Šumava-Churáňov, Sum_M Šumava - Mokrůvka, Jiz - Jizerské hory Mtsn.s. - not sampled

Table $5 \delta^{2} \mathrm{H}$ and $\delta^{18} \mathrm{O}$ values of fog, rain and throughfall samples averaged for each of the regions.

\begin{tabular}{|c|c|c|c|c|c|c|c|}
\hline \multirow[t]{2}{*}{ Site } & \multirow[t]{2}{*}{ Dates sampled } & \multicolumn{3}{|c|}{$\delta^{2} \mathbf{H}[\%$ o] } & \multicolumn{3}{|c|}{$\delta^{18} \mathrm{O}[\% \mathrm{o}]$} \\
\hline & & $\mathbf{F}$ & $\mathbf{R}$ & $\mathbf{T}$ & $\mathbf{F}$ & $\mathbf{R}$ & $\mathbf{T}$ \\
\hline Krkonoše & 2/16/27.10 & -53.1 & -68.8 & -72.0 & -8.5 & -10.3 & -10.7 \\
\hline Šumava & 2,24,25.10/7,9,14.11. & -57.9 & -64.7 & -64.6 & -9.0 & -10.1 & -9.8 \\
\hline Jizerské hory & $6.10 / 6.11$ & -51.2 & -59.5 & n. s. & -8.5 & -9.4 & n. s. \\
\hline
\end{tabular}

Note: F - fog, R - rain, T - throughfall, Krk_SH - Krkonoše-Studniční hora, KrK_LB - Krkonoše-Labská bouda, Sum_CH - Šumava-Churáňov, Sum_M Šumava - Mokrůvka, Jiz - Jizerské hory Mts., n.s. - not sampled

exceptions (indicated in italics in Table 3), which was expected. Throughfall was generally depleted compared to rain, however, which is the opposite of what was assumed. Furthermore, the $\delta^{2} \mathrm{H}$ and $\delta^{18} \mathrm{O}$ values of rain and throughfall were quite similar in many cases.

Table 6 presents the percentage of fog in throughfall in individual samples. It is obvious that the percentage for most samples is unrealistic as they are outside the reasonable range of 0-100\%. Only a few samples yielded realistic percentages ranging between 3 and $8 \%$ based on $\delta^{2} \mathrm{H}$ and 4 and $7 \%$ based on $\delta^{18} \mathrm{O}$.

\section{Discussion}

\section{Comparison of our results on the hydrogen and oxygen stable isotope compositions of fog, rain and throughfall with those reported in similar studies}

The hydrogen and oxygen stable isotope composition of rain can be compared with that reported for other parts of the CR, as there is an ongoing long-term study of the experimental catchment Uhlírská in the Jizerské hory Mts., which is part of the international GNIP and GNIR networks (Vitvar et al. 2007; IAEA/WMO 2020). The 
Table 6 Percentage of fog in throughfall.

\begin{tabular}{|l|c|c|c|}
\hline \multirow{2}{*}{ Site } & \multirow{2}{*}{ Date } & \multicolumn{2}{|c|}{ Percentage of fog [\%] } \\
\cline { 3 - 4 } & & based on $\mathbf{\delta}^{\mathbf{2}} \mathbf{H}$ & based on $\mathbf{~} \mathbf{1 8}^{\mathbf{O}}$ \\
\hline KrK_SH & 2.10. & -32.3 & -38.4 \\
\hline KrK_SH & 16.10. & -45.2 & -70.9 \\
\hline KrK_LB & 2.10. & -4.9 & $\mathbf{3 . 5}$ \\
\hline KrK_LB & 16.10. & -21.5 & $-8,8$ \\
\hline KrK_LB & 27.10. & -10.4 & -7.0 \\
\hline Sum_CH & 2.10. & -181.1 & -26.4 \\
\hline Sum_CH & 24.10. & -44.7 & -52.6 \\
\hline Sum_CH & 7.11. & $\mathbf{3 . 2}$ & $\mathbf{7 . 4}$ \\
\hline Sum_CH & 9.11. & $\mathbf{3 . 2}$ & $\mathbf{5 . 4}$ \\
\hline Sum_M & 25.10. & $\mathbf{7 . 8}$ & 112.8 \\
\hline Sum_M & 14.11. & -18.3 & 142.5 \\
\hline
\end{tabular}

Note: Krk_SH - Krkonoše-Studniční hora, KrK_LB - Krkonoše-Labská bouda, Sum_CH - Šumava-Churáňov, Sum_M - Šumava-Mokrůvka, Jiz Jizerské hory Mts., realistic fraction of fog in bold

measurements for October-November 2007-2016 reported by Šanda et al. (2019) indicate that $\delta^{18} \mathrm{O}$ is around $-10 \%$, which is similar to our results. For Churánov in the Šumava Mts., Vystavna et al. (2018) report $\delta^{18} \mathrm{O}$ values in monthly samples of between $-14.5 \%$ and $-7.1 \%$ o and $\delta^{2} \mathrm{H}$ values of between $-100.3 \%$ and $-45 \%$, with volume-weighted averages for $\delta^{18} \mathrm{O}$ and $\delta^{2} \mathrm{H}$ in precipitation over the entire period studied (November 2016 October 2017 ) of $-10.4 \%$ and $-71 \%$, respectively. For Vysoké Tatry in neighbouring Slovakia, Holko et al. (2018) report values ranging from $-70 \%$ o to $-45 \%$ for $\delta^{2} \mathrm{H}$ and $-10 \%$ to $-5 \%$ o for $\delta^{18} \mathrm{O}$, and $-50 \%$ o to $-35 \%$ o for $\delta^{2} \mathrm{H}$ and $-8 \%$ to $-6 \%$ for $\delta^{18} \mathrm{O}$, for Škaredý potok (altitude of 800-1800 m a.s.l.) and Jalovecký potok (altitude of $800-1500 \mathrm{~m}$ a.s.l.), respectively. The values for Slovakia are thus somewhat higher.
Throughfall is expected to be richer in heavier isotopes compared to rain due to increased evaporation and sublimation. The enrichment values in scientific literature are not substantial, however. For spruce trees in a densely forested catchment in Germany it is enriched by only up to $1 \%$ for $\delta^{18} \mathrm{O}$ (Brodersen et al. 2000) and the maximum throughfall $\delta^{18} \mathrm{O}$ enrichment of $1.61 \%$ is reported for a spruce forest located in central Pennsylvania, U.S., in spring (Dewalle and Swistock 1994). For pine forest the average $\delta^{18} \mathrm{O}$ enrichment is even lower, $-0.3 \%$ (Saxena 1986). In contrast to the above reports and our assumption, our throughfall samples were depleted in heavier isotopes relative to rain in most cases.

Our results for fog cannot be compared with other studies from Central Europe or even the CR, as such information is not available. They compare well with the values for different regions of the world cited by Scholl et al. (2011), which range, however, widely between -71 and $+13 \%$ for $\delta^{2} \mathrm{H}$ and -10.4 and $+2 \%$ for $\delta^{18} \mathrm{O}$.

\section{The contribution of fog to throughfall}

The contribution of fog to atmospheric deposition might be substantial, as it is usually much more concentrated than rain in particular regions. This is not surprising, as fog generally forms much lower in the atmosphere and close to the ground, in areas with higher particulate and gaseous concentrations than rain (Seinfeld and Pandis 2006; Hůnová et al. 2018). That fogs are usually substantially enriched in ions, in particular those of environmentally important substances, is documented for many regions of the world (Bridges et al. 2002; Blaš et al. 2012). However, it is difficult to estimate the contribution of fog water contribution and reliably quantify the deposition fluxes for respective ions. As fog and rain often co-exist in a mixed form, it is difficult to distinguish between them and trace those separately

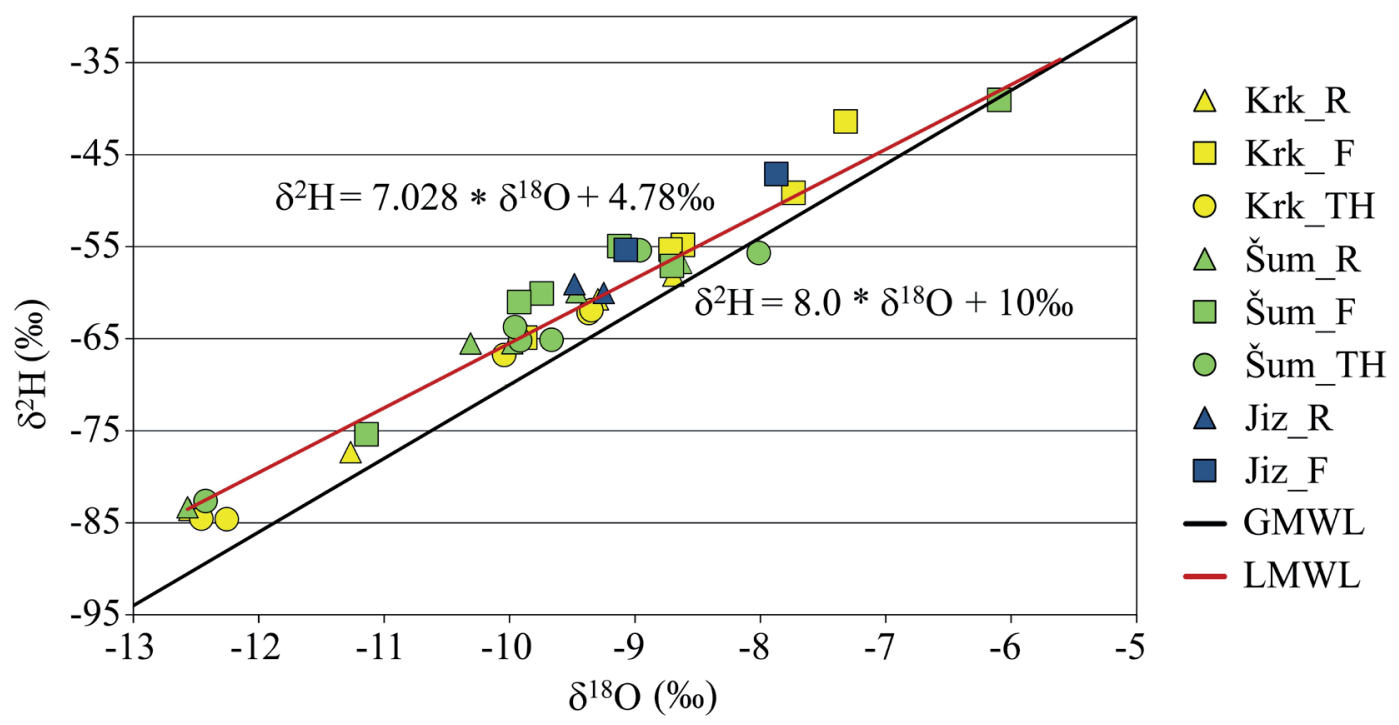

Fig. 3 The relationship between the $\delta^{18} \mathrm{O}$ and $\delta^{2} \mathrm{H}$ values for fog, rain and throughfall in the regions studied (R - rain, $\mathrm{F}-\mathrm{fog}$, TH - throughfall, Krk - Krkonoše Mts., Šum - Šumava Mts., Jiz - Jizerské hory Mts., GMWL - Global Meteoric Water Line, LMWL - Local Meteoric Water Line). 
using traditional methods. Nevertheless, due to different condensation conditions and processes, fog water and rainwater have typical fingerprints and can be distinguished by differences in their isotopic composition (Scholl et al. 2002, 2011).

There are many studies on the stable isotope compositions of fog, rain and throughfall mainly in cloud montane forests (e.g. Chang et al. 2002; Eugster et al. 2006; Eugster 2007), some of which use simple mixing model to estimate the contribution of fog to throughfall. Simple isotope mixing model is a good tool for assessing the fog content of throughfall for many precipitation events. Nevertheless, some authors report unrealistic results. For example, Schmid et al. (2011) indicate that almost half of the events during a three-months long study conducted in cloud forest in Costa Rica in 2003 resulted in percentages outside the valid range of $0-100 \%$, and conclude that this approach needs further refinements. In addition, the percentages obtained using this technique were lower than those obtained using the eddy covariance method (Eugster 2007).

In our study, the percentage of fog water fraction in throughfall was about $5 \%$, which is lower than originally expected. Tesař et al. (2000), using a different approach, however, report that fog makes up 10\% and 15-20\% of precipitation in the Šumava and the Krkonoše Mts., respectively. As fog in mountain regions in the Czech Republic occur most frequently during autumn and winter (Tolasz et al. 2007; Hůnová et al. 2020), which is when we collected our samples, the expectation was that the percentage contribution of fog over an entire year would be considerably lower than that reported for October and November. The above is very different from Tesar et al. (2004) estimates despite the fact that they are based on the percentage of fog in precipitation collected from a sampler located outside the forest, whereas we measured the percentage of fog in throughfall collected under the canopy of trees. Generally, throughfall is some $20 \%$ lower than the amount in precipitation collected outside a forest (CHMI 2019). Interestingly, some studies in the Central European region, using different approaches, however, estimate much higher contributions of fog. For example, Lange et al. (2003) for a site in the Erzgebirge Mts. In Germany estimate that fog makes about 25\% of the annual precipitation, whereas Blaš et al. (2010) report that the percentage for the Sudeten Mts. in neighbouring Poland might be $60 \%$.

\section{The limitations of this study}

Although the IRMS analysis is very reliable and accurate, the sampling procedure might have introduced errors. In contrast to sampling rain, which might be considered relatively easy and straightforward, the sampling of both fog and throughfall is challenging (Scholl et al. 2011). In areas with mixed fog and rain precipitation, passive fog samplers (which were used at all sites in this study except Churáňov), generally collect some wind-driven rain as their shields are not capable of completely excluding rain (Fischer and Still 2007). This might be an issue especially in the Krkonoše Mts., where both sampling sites, due to their location in open un forested areas at high altitudes, were exposed to strong winds (Tolasz et al. 2007). For collecting throughfall, the positioning of the sampler underneath the canopy is reported to be important (Brodersen et al. 2000). A major difficulty in sampling throughfall is high spatial and temporal variability and consequent difficulties in ensuring sample representativeness (Beier et al. 1993; Keim et al. 2005; Hansen et al. 2013). In addition, whereas the positioning of the throughfall samplers in spruce forests in the Šumava and Jizerské hory Mts. was easy due to the canopy structure and architecture of the trees, it was much more challenging underneath dwarf pines in the Krkonoše Mts.

In addition, the storage and manipulation of samples could cause problems because the stable isotope composition can be substantially changed by evaporation and/or exchange with ambient water vapour (Ingraham and Criss 1993). The essential prerequisite is therefore to avoid changes in isotopic composition between collection and the IRMS analysis. For this reason, some authors recommend the sample to be covered with a $\mathrm{ca}$ $1 \mathrm{~cm}$-thick layer of mineral oil (Scholl et al. 2011). We did not do this, however, as a portion of each sample was used for the ion analysis and could not be used if it was contaminated with mineral oil.

In addition, there is an unassessed uncertainty because the dissolved organic matter in samples of throughfall contains $\mathrm{O}$ and $\mathrm{H}$ that might interfere with $\mathrm{O}$ and $\mathrm{H}$ incorporated in water molecules (Van Stan and Stubbins 2018).

\section{Conclusions}

Our results indicate that fog water is enriched in heavier isotopes relative to rainwater in all three regions studied. The differences in $\delta^{18} \mathrm{O}$ and $\delta^{2} \mathrm{H}$ in rainwater and throughfall water were subtle, however, contrary to our assumptions, rainwater was often enriched in heavier isotopes relative to throughfall water. Hence the simple mixing model worked only in a few cases, indicating that fog contribution to throughfall is $5 \%$, which is lower than that expected based on the results of other studies carried out in the same regions, and substantially lower than in adjacent mountain regions in Germany and Poland. Though the IRMS analysis is reliable, the sampling of precipitation, particularly in mountain regions with extreme meteorological conditions including strong winds make it very difficult to separate the different types of precipitation (i.e. fog, rain and throughfall). The stable isotopic approach is suitable for this kind of study providing careful attention is paid to sampling precipitation and avoiding changes in isotopic composition during storage. 


\section{Acknowledgements}

Part of the equipment used in this study was purchased from the Operational Programme Prague - Competitiveness (Project CZ.2.16/3.1.00/21516). Institutional funding for K. J. was provided by the Centre for Geosphere Dynamics [grant number UNCE/SCI/006]. In addition, the research was funded by the Czech Science Foundation, project GA20-00788S. We thank Jana Schovánková of the Czech Hydrometeorological Institute for preparing Figures 1 and 3.

\section{REFERENCES}

Amodio M, Catino S, Dambruoso PR, de Gennaro G, Di Gilio A, Giundato P, Laiola E, Marzocca A, Mazzone A, Sardaro A, Tutino M (2014) Atmospheric Deposition: Sampling Procedures, Analytical Methods, and Main Recent Findings from the Scientific Literature. Adv Meteorol ID 161730.

Beier C, Hansen K, Gundersen P (1993) Spatial variability of throughfall fluxes in a spruce forest. Environ Pollut 81: $257-267$.

Bellot J, Avila A, Rodrigo A (1999) Throughfall and Stemflow. In: Roda F, Retana J, Gracia CA, Bellot J (eds) Ecology of Mediterranean Evergreen Oak Forests. Ecological Studies (Analysis and Synthesis) 137: 209-222. Springer, Berlin, Heidelberg.

Blaš M, Polkowska Z, Sobik M, Klimaszewska K, Nowinski K, Namiesnik J (2010) Fog water chemical composition in different geographic regions of Poland. Atmos Res 95: 455-469.

Blaš M, Sobik M, Polkowska Ž, Cichaia-Kamrowska K, Namiešnik J (2012) Water and Chemical Properties of Hydrometeors over Central European Mountains. Pure Appl Geophys 169: 10671081.

Bridges KS, Jickells TD, Davies TD, Zeman Z, Hůnová I (2002) Aerosol, precipitation and cloud water observations on the Czech Krusne Hory plateau adjacent to a heavily industrialised valley. Atmos Environ 36: 353-360.

Bridgman HA, Davies TD, Jickells TD, Hůnová I, Tovey K, Bridges K, Surapipith V (2002) Air pollution in the Krusne Hory region, Czech Republic during the 1990s. Atmos Environ 36: 3375-3389.

Brodersen C, Pohl S, Lindenlaub M, Leibundgut C, Wilpert $\mathrm{K}$ (2000). Influence of vegetation structure on isotope content of throughfall and soil water. Hydrol Process 14: 1439-1448.

CHMI (Czech Hydrometeorological Institute) (2019) Air Pollution in the Czech Republic in 2018. Czech/English. CHMI, Prague.

Chang SC, Lai IL, Wu JT (2002) Estimation of fog deposition on epiphytic bryophytes in a subtropical montane forest ecosystem in northeastern Taiwan. Atmos Res 64: 159-167.

ČMES (2020) Elektronický meteorologický slovník výkladový a terminologický (eMS). http://slovnik.cmes.cz. Accesses 1 July 2020.

Daube B, Kimball KD, Lamar PA, Weathers KC (1987) Two new ground-level cloud water sampler designs which reduce rain contamination. Atmos Environ 21: 893-900.

Dawson TE (1998) Fog in the California redwood forest: ecosystem inputs and use by plants. Oecologia 117: 476-485.

Dewalle D, Swistock BR (1994) Differences in oxygen-18 content of throughfall and rainfall in hardwood and coniferous forests. Hydrol Process 8: 75-82.

Eliáš V, Tesař M, Buchtele J (1995) Occult precipitation: sampling, chemical analysis and process modelling in the Sumava Mts.
(Czech Republic) and in the Taunus Mts. (Germany). J Hydrol 166: 409-420.

Eugster W (2007) The relevance of fog for the vegetation: is it the water or the nutrients that matter? In: Biggs A, Cereda P (eds) Proceedings of the Fourth International Conference on Fog, Fog Collection and Dew, La Serena, Chile, 22-27 July 2007, pp 359-362.

Eugster W, Burkard R, Holwerda F, Scatena FN, Bruijnzeel LAS (2006) Characteristics of fog and fogwater fluxes in a Puerto Rican elfin cloud forest. Agric Forest Meteorol 139: 288-306.

Fischer DT, Still CJ (2007) Evaluating patterns of fog water deposition and isotopic composition on the California Channel Islands. Water Resour Res 43: W04420.

Fišák J, Tesar M, Rezacova D, Elias V, Weignerova V, Fottova D (2002) Pollutant concentrations in fog and low cloud water at selected sites of the Czech Republic. Atmos Res 64: 75-87.

Grunow J (1952) Nebelniederschlag [Occult precipitation]. Ber. Deutsch. Wetterd. U.S. Zone 7, Bad Kissinger. 42: 30-34 (in German).

Hansen K, Thimonier A, Clarke N, Staelens J, Žlindra D, Waldner P, Marchetto A (2013) Atmospheric deposition to Forest Ecosystems. In: Ferretti M, Fischer R (eds) Forest Monitoring: Methods for terrestrial investigations in Europe with an overview of North America and Asia. Developments in Environmental Science 12: 337-374. Elsevier, Amsterdam.

Hanusková D (2018) Jak se hydrologicky podílí mlha na atmosférické depozici? Využití stabilních izotopů. Diploma thesis, in Czech. Charles University, Prague.

Holko L, Dóša M, Michalko J, Kostka Z, Šanda M (2012) Isotopes of oxygen-18 and deuterium in precipitation in Slovakia. J Hydrol Hydromech 60: 265-276.

Hůnová I (2020) Ambient Air Quality in the Czech Republic: Past and Present. Atmosphere 11: 214.

Hůnová I, Brabec M, Malý M, Valeriánová A (2018) Revisiting fog as an important constituent of the atmosphere. Sci Total Environ 636: 1490-1499.

Hůnová I, Brabec M, Malý M, Valeriánová A (2020) Long-term trends in fog occurrence in the Czech Republic, Central Europe. Sci Total Environ 711: 135018.

Hůnová I, Kurfürst P, Maznová J, Coňková M (2011) Contribution of occult precipitation to sulphur deposition in the Czech Republic. Erdkunde 65: 247-259.

Hůnová I, Kurfürst P, Vlček O, Stráník V, Stoklasová P, Schovánková J, Srbová D (2016) Towards a better spatial quantification of nitrogen deposition: A case study for Czech forests. Environ Pollut 213: 1028-1041.

IAEA/WMO (2020) Global network for isotopes in precipitation. http://www-naweb.iaea.org/napc/ih/IHS_resources_gnip.html. Accessed 7 July 2020.

Ichiyanagi K (2007) Review: Studies and Applications of stable Isotopes in Precipitation. J Jpn Hydrol Sci 37: 165-186.

Igawa M, Matsumura K, Okochi H (2002) High Frequency and large Deposition of Acid Fog on High Elevation Forest. Environ Sci Technol 36: 1-6.

Ingraham NL, Criss RE (1993) Effects of surface area and volume on the rate of isotopic exchange between water and water vapor. J Geophys Res - Atmos 98: 20547-20553.

Kaseke KF, Tian C, Wang L, Seely M, Vogt R, Wassenaar T, Mushi R (2018) Fog Spatial Distributions over the Central Namib Desert - An Isotope Approach. Aerosol Air Qual Res 18: 49-61.

Keim RF, Skaugset AE, Weiler M (2005) Temporal persistence of spatial patterns in throughfall. J Hydrol 314: 263-274.

Křeček J, Palán L, Stuchlík E (2017) Acid atmospheric deposition in a forested mountain catchment. iForest 10: 680-686. 
Lange CA, Matschullat J, Zimmermann F, Sterzik G, Wienhaus O (2003) Fog frequency and chemical composition of fog water - a relevant contribution to atmospheric deposition in the eastern Erzgebirge, Germany. Atmos Environ 37: 3731-3739.

Nelson (2000) A simple, practical methodology for routine VSMOW/SLAP normalization of water samples analysed by continuous flow methods. Rapid Communication in Mass Spectrometry 14: 1044-1046.

Palán L, Křeček J (2018) Interception and fog drip estimates in fragmented mountain forests. Environ Process 5: 727-742.

Rogora M, Mosello R, Arisci S, Brizzio MC, Barbieri A, Balestrini R, Waldner P, Schmitt M, Stahli M, Thimonier A, Kalina M, Puxbaum H, Nickus U, Ulrich E, Probst A (2006) An overview of atmospheric deposition chemistry over the Alps: present status and long-term trends. Hydrobiologia 562: 17-40.

Rozanski K, Araguás-Araguás L, Gonfiantini R (1992) Relation between long-term trend of oxygen-18 isotope composition of precipitation and climate. Science 258: 981-989.

Saxena RK (1986) Estimation of canopy reservoir and oxygen fractionation in throughfall in alpine forest. Nord Hydrol 17: 251-260.

Schemenauer RS, Cereceda P (1994) A proposed standard fog collector for use in high-elevation regions. J Appl Meteorol 33: 1313-1322.

Schmid S, Burkard R, Frumau KFA, Tobón C, Bruijnzeel LA, Siegwolf R, Eugster W (2011) The wet canopy water balance of a Costarican cloud forest during the dry season. In: Bruijnzeel LA, Scatena FN, Hamilton LS (eds) Tropical Montane Cloud Forests: Science for Conservation and Management. Cambridge University Press, Cambridge.

Scholl MA, Giambelluca TW, Gingerich SB, Nullet MA, Loope LL (2007) Cloud water in windward and leeward mountain forests: The stable isotope signature of orographic cloud water. Water Resou Res 43: W12411.

Scholl MA, Gingerich SB, Tribble GW (2002) The influence of microclimates and fog on stable isotope signatures used in interpretation of regional hydrology: East Maui, Hawaii. J Hydrol 264: 170-184.

Scholl M, Eugster W, Burkard R (2011) Understanding the role of fog in forest hydrology: stable isotopes as tools or determining input and partitioning of cloud water in montane forests. Hydrol Process 25: 353-366.

Seinfeld JH, Pandis SN (2006) Atmospheric Chemistry and Physics. From Air Pollution to Climate Change. Second Edition. John Wiley and Sons, Inc., Hoboken, New Jersey.

Sharp Z (2007) Principles of Stable Isotope Geochemistry. 2nd edition. On-line version. https://digitalrepository.unm.edu /unm_oer/1/. Accessed 20 June 2020.

Soulsby C, Malcolm R, Helliwell R, Ferrier RC, Jenkins A (2000) Isotope hydrology of the Allt a'Mharcaidh catchment, Cairngorms, Scotland: implications for hydrological pathways and residence times. Hydrol Process 14: 747-762.
Šanda M, Vitvar T, Holko I, Blažková Š, Bůzek F et al. (2011) Využití stabilních izotopů vodíku a kyslíku v hydrologii malých experimentálních povodí České a Slovenské republiky. Hydrologie malého povodí 2011. Ústav pro hydrodynamiku AVČR, v. v. i., Praha, pp 419-435.

Šanda M, Vitvar T, Jankovec J (2019) Seasonal subsurface water contributions to baseflow in the mountainous Uhliŕská catchment (Czech Republic). J Hydrol Hydromech 67: 41-48.

Šantrůček J, Šantrůčková H et al. (2018) Stabilní izotopy biogenních prvků. Použití v biologii a ekologii. Academia, Praha.

Šír M, Tesař M (2013) Water retention and runoff formation in the Krkonoše Mts. Opera Corcontica 50: 97-106.

Tesař M, Eliáš V, Šír M (1995) Preliminary results of characterization of cloud and fog water in the mountains of Southern and Northern Bohemia. J Hydrol Hydromech 43: 412-426.

Tesař M, Fottová D, Eliáš V, Šír M (2000) Occult precipitation as an important contribution to the wet deposition in Bohemian Forest. Silva Gabreta 4: 87-96.

Tesař M, Sir M, Fottova D, Fisak J, Elias V (2001) Cloud and Fog Water Deposition and its Hydrological and Ecological Importance in Selected Regions of the Czech Republic. In: Schemenauer R, Puxbaum H (eds) Proceedings of Second International Conference on Fog and Fog Collection, pp 153-156.

Tolasz R, Míková T, Valeriánová A, Voženílek V (2007) Atlas podnebí Česka. ČHMÚ a Univerzita Palackého, Praha a Olomouc.

Van Stan JT, Stubbins A (2018) Tree-DOM: Dissolved organic matter in throughfall and stemflow. Limnol Oceanogr Lett 3: 199-214.

Vitvar T, Aggarwal PK, Herczeg AL (2007) Global network is launched to monitor isotopes in rivers. EOS Transactions American Geophysical Union 88: 325-326.

Votrubová J, Dohnal M, Vogel T, Sanda M, Tesar M (2017) Episodic runoff generation at Central European headwateer catchments studied using water isotope concentration signals. J Hydrol Hydromech 65: 114-122.

Vystavna Y, Holko L, Hejzlar J, Persoiu A, Graham ND, Juras R, Huneau F, Gibson J (2018) Isotopic response of run-off to forest disturbance in small mountain catchments. Hydrol Process 37: 3650-3661.

Weathers KC, Likens GE, Bormann FH, Bicknell SH, Bormann BT, Daube BC, Eaton JS, Galloway JN (1988) Cloud water chemistry from ten sites in North America. Environ Sci Technol 22: 1018-1025.

Weathers KC, Ponette-Gonzáles AG, Dawson TE (2020) Medium, Vector, and Connector: Fog and the Maintenance of Ecosystems. Eosystems 23: 217-229.

Zhan L, Chen J, Li L (2017) Isotopic assessment of fog drip contribution in vegetation during dry season in Junshan wetland, northern Dongting Lake. Wetlands Ecol Manage 25: 345-357. 